\title{
A FRAMEWORK FOR AGRICULTURAL ADAPTATION TO CLIMATE CHANGE IN SOUTHERN NIGERIA
}

\author{
NICHOLAS OZOR ${ }^{1 *}$, MADUKWE M.C. ${ }^{1}$, ENETE A.A. ${ }^{2}$, AMAECHINA E.C. ${ }^{2}$, ONOKALA P. ${ }^{3}$, EBOH E.C. ${ }^{4}$, \\ UJAH 0.4, AND GARFORTH C.J. ${ }^{5}$
}

\author{
1Department of Agricultural Extension, University of Nigeria, Nsukka. \\ 2Department of Agricultural Economics, University of Nigeria, Nsukka. \\ ${ }^{3}$ Department of Geography, University of Nigeria, Nsukka. \\ ${ }^{4}$ African Institute for Applied Economics, Enugu. \\ 5International and Rural Development Department, University of Reading, UK. \\ ${ }^{*}$ Corresponding Author: Email- sunny_ozor@yahoo.com
}

Received: June 18, 2012; Accepted: June 28, 2012

\begin{abstract}
The agricultural sector which contributes between $20-50 \%$ of gross domestic product in Africa and employs about $60 \%$ of the population is greatly affected by climate change impacts. Agricultural productivity and food prices are expected to rise due to this impact thereby worsening the food insecurity and poor nutritional health conditions in the continent. Incidentally, the capacity in the continent to adapt is very low. Addressing these challenges will therefore require a holistic and integrated adaptation framework hence this study. A total of 360 respondents selected through a multi-stage random sampling technique participated in the study that took place in Southern Nigeria from 2008-2011. Results showed that majority of respondents (84\%) were aware that some climate change characteristics such as uncertainties at the onset of farming season, extreme weather events including flooding and droughts, pests, diseases, weed infestation, and land degradation have all been on the increase. The most significant effects of climate change that manifested in the area were declining soil fertility and weed infestation. Some of the adaptation strategies adopted by farmers include increased weeding, changing the timing of farm operations, and processing of crops to reduce post-harvest losses. Although majority of respondents were aware of government policies aimed at protecting the environment, most of them agreed that these policies were not being effectively implemented. A mutually inclusive framework comprising of both indigenous and modern techniques, processes, practices and technologies was then developed from the study in order to guide farmers in adapting to climate change effects/impacts.
\end{abstract}

Key words- Framework, Agricultural adaptation, Mitigation, Climate change, Effects, Impacts, Southern Nigeria.

Citation: Nicholas Ozor, et al. (2012) A Framework for Agricultural Adaptation to Climate Change in Southern Nigeria. International Journal of Agriculture Sciences, ISSN: 0975-3710 \& E-ISSN: 0975-9107, Volume 4, Issue 5, pp-243-252.

Copyright: Copyright@2012 Nicholas Ozor, et al. This is an open-access article distributed under the terms of the Creative Commons Attribution License, which permits unrestricted use, distribution and reproduction in any medium, provided the original author and source are credited.

\section{Introduction}

There is wide acceptance by stakeholders that climate change will affect all nations especially the developing ones like those in Africa. The Intergovernmental Panel on Climate Change (IPCC) already predicted that Africa is the most vulnerable to climate change impacts [1]. However, it is saddening to note that Africa contributes less than $4 \%$ of the greenhouse gas emissions that contribute to climate change and yet is most vulnerable to the impacts of the change. The adverse effects on poor people and poor countries in the continent are particularly severe because these people and countries depend more directly on natural re- sources and are less able to adapt to climate variations and extreme weather. Poor people in developing countries especially in sub Saharan Africa are affected by environmental change because they are much more exposed to existential risks such as disease, hunger, low income and most importantly poor adaptive capacities [2].

Climate change will affect all economic sectors of Africa and will therefore present unprecedented challenges for the continent, particularly in terms of meeting its sustainable development objectives, including the millennium development goals (MDGs). Indeed, climate change is already eroding decades of hard-won 
national and international development gains, thus the need for concerted and coherent efforts in urgently tackling the development challenge. This challenge has further exacerbated poverty in Africa as rising temperature and sea level results in undue flooding, droughts, and salinization in low lying areas. Reconnaissance surveys and pan-African stakeholder consultations carried out by the African Technology Policy Studies Network (ATPS) and its partners, including the United Nations Environment Program (UNEP) in 2007, 2008 and 2009 show that the sectors that are most likely to be affected by climate variability in Africa are agriculture, water and biodiversity. These sectors were prioritized as most critical as they will have direct impacts on rural livelihoods. Incidentally, agriculture is the mainstay of many countries' economies in Africa contributing between $20-50 \%$ of the gross domestic product (GDP), employing over $70 \%$ of the population, and mostly dependent on weather and climate [3, 4]. This means that any change in weather and climate will have catastrophic consequences on agricultural production, economy, employment and overall livelihoods of the most affected groups in the continent including farmers, pastoralists, foresters, fisher folks and hunters. The consultation exercise led by the ATPS also found that other factors such as increased intensity, frequencies, prevalence and uncertain patterns of land degradation, pests and diseases, droughts, flooding events and most importantly low technical and innovation capacities to adapt to these changes are the most significant indicators of farmers' inability to implement, create, alter, and implement multiple adaptive measures. In other words, the individual, community and institutional capacity to adapt to the shifting climate change impacts while continuing to function effectively i.e. their capacities, are very low. Even where this resilience exists, they are not well documented especially in Africa so as to create the opportunity for up scaling and replication in other vulnerable areas.

It is then less difficult to believe that agricultural productivity under the prevailing climate change situation in most developing countries will be very low. Consequently, the low crop yield will lead to unavoidable shocks to the already fragile economies in African countries. Food prices are expected to rise, worsening the food insecurity and poor nutritional health conditions in the continent. The impacts of climate change on food production, prices and food security depend on regional climate change, biological effects of increasing atmospheric carbon dioxide, changes in floods, droughts and other extreme events, existing agricultural systems, adaptive capacity, changes in population, economic growth and technological innovation [5]. A clear case example is the drought and food crisis situation that has been ravaging the horn of Africa (particularly Somalia, Northern Kenya, Ethiopia, Djibouti and Eritrea) since the second quarter of 2011 which has claimed many human lives, led to the death of millions of animals and livestock and has predisposed millions of people to health and nutritional challenges.

Article 2 of the United Nations Framework Convention on Climate Change (UNFCCC) is aimed towards 'ensuring that food production is not threatened'. In assessing the climate change impacts on food production, the adaptive capacity of agricultural systems has to be taken into consideration [6]. This capacity differs substantially between regions. Unfortunately, the regions affected most are the ones with the least adaptive capacity - i.e. the devel- oping countries [7].

Addressing Africa's climate change challenges will therefore require a holistic and integrated adaptation framework [4]. While adaptation is the process of responding or adjusting to actual and potential impacts of changing climate conditions in ways that moderate harm or take advantage of any positive opportunities that it may afford, it remains the most popular option to manage the impacts of climate change on agriculture in the world today. It also includes policies and measures to reduce exposure to climate variability and extremes and the strengthening of adaptive capacity. It requires changes in knowledge, attitudes, resilience capacities, and skills of the people. However, neither adaptation nor mitigation actions alone can prevent significant climate change impacts; taken together, they can significantly reduce food security risks. While mitigation is necessary to reduce the rate and magnitude of climate change, adaptation is essential to reduce the damages from climate change that cannot be avoided [8].

The pertinent questions to ask therefore are: Are farmers aware of climate change? What are the impacts of climate change on agriculture in the study area? What are the human activities in the area that exacerbate climate change incidence? Are farmers in rural areas capable of adapting to the impacts of climate change? If yes, what are the strategies they have adopted in coping with the incidences of the change? What socioeconomic factors influence farmers' adaptation capacity? Which adaptation framework can be propagated to increase adaptation capacity of farmers in the area? This paper focuses on providing answers to these questions.

\section{Purpose and Objectives}

The overall purpose of the study was to develop a framework for agricultural adaptation to climate change in Southern Nigeria. Specifically, the study was meant to:

1. ascertain the awareness level of farmers to climate change;

2. examine the effects/impacts of climate change on agriculture in the area;

3. identify the human causal factors to climate change in the area;

4. identify the strategies for agricultural adaptation to climate change and determine the socioeconomic factors influencing farmers' adaptation to climate change;

5. identify existing government policies and programmes on climate change adaptation; and

6. develop a framework for agricultural adaptation to climate change.

\section{Methodology \\ The Study Area}

The study area is Southern Nigeria (Fig. 1) comprising of three geopolitical zones namely; South East, South West and SouthSouth. Its climate is characterized by strong latitudinal zones, becoming progressively drier as one moves north from the coast. Rainfall is the key climatic variable, and there is a marked alternation of wet and dry seasons in most areas. Two air masses control rainfall-moist northward-moving maritime air coming from the Atlantic Ocean and dry continental air coming south from the African landmass. 


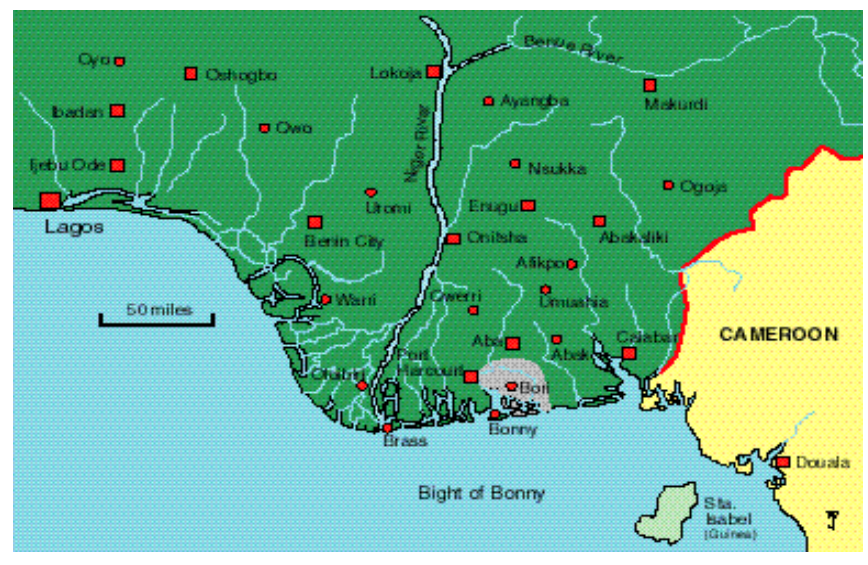

Fig. 1- Map of Southern Nigeria

The rainy season usually begins in February or March as moist Atlantic air, known as the southwest monsoon, invades the country. The beginning of the rains is usually marked by the incidence of high winds and heavy but scattered squalls. By April or early May in most years, the rainy season is under way throughout most of the area. The usual peak of the rainy season occurs through most of southern Nigeria in July with a dip in precipitation during the month of August. Although rarely completely dry, this August dip in rainfall, which is especially marked in the southwest, can be useful agriculturally, because it allows a brief dry period for grain harvesting.

From September through November, the northeast trade winds generally bring a season of clear skies, moderate temperatures, and lower humidity for most of the country. From December through February, however, the northeast trade winds blow strongly and often bring with them a load of fine dust from the Sahara. These dust-laden winds, known locally as the harmattan, often appear as a dense fog and cover everything with a layer of fine particles.

The greatest total precipitation is generally in the south-south; along the coast around Bonny (south of Port Harcourt) and east of Calabar, where the mean annual rainfall is more than 4,000 millimetres. Most of the rest of the south-south and southeast receives between 2,000 and 3,000 millimetres of rain per year, and the southwest (lying farther north) receives lower total rainfall, generally between 1,250 and 2,500 millimetres per year. Mean annual precipitation at Lagos is about 1,900 millimetres; at Ibadan, only about 140 kilometres north of Lagos, mean annual rainfall drops to around 1,250 millimetres. Moving north from Ibadan, mean annual rainfall in the west is in the range of 1,200 to 1,300 millimetres.

Temperatures throughout Nigeria are generally high; diurnal variations are more pronounced than seasonal ones. Highest temperatures occur during the dry season; rains moderate afternoon highs during the wet season.

The economy of Nigeria historically was based on agriculture, and about 70\% of the workforce is still engaged in farming (largely of a subsistence type). The chief crops are cocoa, peanuts, palm oil, corn, rice, sorghum, millet, soybeans, cassava, yams and rubber. In addition, cattle, sheep, goats and pigs are raised.

The distribution of vegetation in Southern Nigeria is dependent mainly on the climate, which becomes increasingly drier further inland from the coast. Climatic zones, therefore, run roughly parallel to the coast, widening or narrowing as geographical features alter the steepness of the climatic gradient. This climatic zonation has resulted in a vegetation zonation, comprising the rain forest zone, the mixed deciduous forest zone, and the parkland zone. The first two are climax systems, but the parkland zone is probably caused by anthropogenic conversion of forest and is maintained by annual bush fires. The natural vegetation of the parkland zone would probably be mixed deciduous forest. Typical mean annual rainfall varies from 2,000 to 2,500 millimeters $(\mathrm{mm})$ in the rain forest zone near the coast to 1,500 to $2,000 \mathrm{~mm}$ in the mixed deciduous forest zone.

\section{Sampling Procedure and Data Collection}

Multistage random sampling technique was employed in the selection of respondents for the study, which covered the three geopolitical zones of southern Nigeria and was conducted in 2009/2010. In each zone, two states were randomly selected to make a total of six states. These were Abia and Enugu in Southeast, Cross River and Delta in south-south, and Ogun and Ondo in southwest. In each state, two agricultural zones were randomly selected to make a total of twelve agricultural zones. These were Umuahia and Aba in Abia State, Enugu and Nsukka in Enugu State, Ikom and Calabar in Cross River State, Delta Central and Delta North in Delta State, Rainforest and Savanna in Ogun State, Ondo central and Ondo North in Ondo State. With the assistance of the respective state extension service departments, one farming community was randomly selected from each agricultural zone, to make a total of twelve communities. These were Oboro and Azumini in Abia State, Umulumgbe and Edem in Enugu State, Ugep and Nkpatum in Cross River State, Okpe and Okoamako in Delta State, Imala and ijebu-ode in Ogun State and Emureile and Adofure in Ondo State. In each community, also with the assistance of the local extension personnel, a list of farm households was compiled and then thirty farmers randomly selected, making a total of three hundred and sixty (360) farmers for the study.

Data were collected using structured interview schedule and questionnaire. The data collected included status of awareness of climate change, effects/impacts of climate change on agriculture, farmers' adaptation strategies and factors influencing their adaptation activities.

\section{Data Analysis}

Data from the study were analysed using both descriptive and inferential statistics. Objective one was analysed using percentage and mean scores while objectives two and three were analysed using mean scores. Objective four was analysed using mean and probit regression. Objective five was analyzed using percentage scores while objective six was described using key results from the study

\section{Results and Discussions Awareness of Climate Change}

Results on farmers' awareness to climate change show that, $84 \%$ of them were aware of it. This suggests a high level of awareness on the subject matter in the area and can be attributed to extensive awareness creation made through the print and electronic media and through other social and religious networks. The re- 
spondents' awareness of climate change was further demonstrated by their response to the question on how they would describe climate change to a friend. Some of the descriptions from the farmers include - prolonged bad weather, change of weather conditions, situation of volatile weather, short rainfall duration and prolonged dry season, thunderstorm and heavy rains, too much rain and too much sun, unpredictable change in the pattern of rainfall, unpredictable start and end of rains, unstable weather, and variation in rainfall pattern and sunshine intensity. The respondents maintained that climate change is said to occur when such conditions as described above persists for a very long period usually in years. The awareness of climate problems and the potential benefits of taking action is an important determinant of adoption of agricultural technologies [9]. It was earlier found out that farmer awareness of change in climate attributes (temperature and precipitation) is important to adaptation decision making [10]. For example, it was earlier reported that farmers' awareness and perceptions of soil erosion problem as a result of changes in climate, positively and significantly affect their decisions to adopt soil conservation measures $[11,12]$.

Similarly, on the question of whether climate change will affect agriculture, the respondents overwhelmingly $(96 \%)$ said yes. The national government in Nigeria already has agencies charged with managing environmental issues such as climate change; for example, the National Emergency Management Agency (NEMA). Such agencies mostly sensitize the people through the radio, newspapers and television in addition to on the ground contacts with vulnerable people. These efforts may explain why there was a high level of awareness of climate change by the respondents.

Regarding changes in climate change variables, results showed that the uncertainties in the onset of farming season have all been increasing in the area (Table 1). These uncertainties include; early rains that are not sustained (77\%), crops planted become smothered by heat waves (69\%), crop planting and replanting $(67 \%)$ and shifts in the start or end of rains $(78 \%)$. This was also the trend (increasing incidences) for extreme weather events such as thunderstorms $(51 \%)$, heavy winds $(54 \%)$, floods $(62 \%)$, drought $(61 \%)$, heat waves $(68 \%)$ and heavy rainfall $(74 \%)$. Other trends that showed increasing incidences were pests $(67 \%)$, diseases $(59 \%)$ and weeds $(73 \%)$. The trends for land degradation properties showed a higher proportion of increases in sheet erosion $(42 \%)$, rill erosion (44\%), gully erosion (46\%), wind erosion (42\%), and declining fertility $(82 \%)$. It was observed that the effects of extreme weather events and uncertainties in the onset of the rainy season on agriculture are particularly more pronounced in the developing world [13]. The elements of climatic change that affect agricultural productivity includes prolonged drought, thunderstorms, flooding of crops fields, erosion of fertile soils, landslides and the falling of tender crop such as maize by wind [14].

The respondents were also asked to indicate the extent to which they think that climate change was responsible for the changes in the variables stated above. Their mean responses showed that all the changes discussed above regarding uncertainties in the onset of the farming season, extreme weather events, pests, diseases and weeds, and land degradation variables, have all to do with climate change (Table 1). The IPCC [1] had already reported that there have been noticeable impacts of climate change on plant production, insect, disease and weed dynamics. Moreover, rising atmospheric $\mathrm{CO}_{2}$ concentrations, higher temperatures, changes in annual and seasonal precipitation patterns and the frequencies of extreme events are the usual features of climate change phenomenon [15]. It was also observed that seasonal changes in rainfall and temperature, which are features of climate change, could impact agro-climatic conditions, altering growing seasons, planting and harvesting calendars, water availability, pest, weed and disease populations [16].

Table 1- Data on direction of change of climate change phenomena and extent of contribution of phenomena to climate change $(n=360)$

\begin{tabular}{|c|c|c|c|c|c|}
\hline $\begin{array}{l}\text { S. } \\
\text { No. }\end{array}$ & $\begin{array}{l}\text { Phenomena you think } \\
\text { have been getting } \\
\text { worse over the past } \\
\text { ten years }\end{array}$ & $\begin{array}{l}\text { Increasing } \\
\text { (IC) }\end{array}$ & $\begin{array}{l}\text { Decreasing } \\
\text { (DC) }\end{array}$ & $\begin{array}{l}\text { No } \\
\text { change } \\
\text { (NC) }\end{array}$ & $\begin{array}{l}\text { Mean extent of } \\
\text { contribution of } \\
\text { climate change to } \\
\text { the phenomenon }\end{array}$ \\
\hline \multicolumn{6}{|c|}{ Uncertainties in the onset of farming season } \\
\hline (i) & $\begin{array}{l}\text { Early rains that are not } \\
\text { sustained }\end{array}$ & 77 & 18 & 50 & 4.2 \\
\hline (ii) & $\begin{array}{l}\text { Crops planted become } \\
\text { smothered by heat } \\
\text { waves }\end{array}$ & 69 & 21 & 9 & 3.9 \\
\hline (iii) & $\begin{array}{l}\text { Crop planting and } \\
\text { replanting }\end{array}$ & 67 & 20 & 13 & 3.7 \\
\hline (iv) & $\begin{array}{l}\text { Shifts in the start or end } \\
\text { of rains }\end{array}$ & $d_{78}$ & 16 & 6 & 4 \\
\hline \multicolumn{6}{|c|}{ Extreme weather events } \\
\hline (i) & Thunderstorms & 51 & 32 & 17 & 3.5 \\
\hline (ii) & Heavy winds & 54 & 29 & 17 & 3.6 \\
\hline (iii) & Floods & 62 & 18 & 20 & 3.5 \\
\hline (iv) & Drought & 61 & 17 & 22 & 3.6 \\
\hline (v) & Heat waves & 68 & 6.9 & 25.1 & 3.8 \\
\hline (vi) & ) Heavy rainfall & 74 & 15 & 11 & 4 \\
\hline Pes & sts & 67 & 14 & 19 & 3.8 \\
\hline & seases & 59 & 18 & 23 & 3.7 \\
\hline We & eeds & 73 & 10 & 17 & 4 \\
\hline \multicolumn{6}{|c|}{ Land degradation } \\
\hline (i) & Sheet erosion & 42 & 29 & 29 & 3.3 \\
\hline (ii) & Rill erosion & 44 & 29 & 27 & 3.4 \\
\hline (iii) & Gully erosion & 46 & 19 & 35 & 3.3 \\
\hline (iv) & Wind erosion & 42 & 24 & 34 & 3.3 \\
\hline (v) & Declining fertility & 82 & 11 & 7 & 4.1 \\
\hline
\end{tabular}

Cut off point $=50 \%$, Cut off $=3.0$

\section{Effects/Impacts of Climate Change on Agriculture}

Table 2 shows the perceived effects/impacts of climate change on agriculture in the study area ascertained using a five point Likerttype scale. Results showed that all the effects/impacts observed have worsened in the past ten years as reported by farmers. The most significant effect/impact of climate change on agriculture was declining soil fertility $(\bar{X}=4.15)$ followed by increased weed infestation $(\bar{X}=4.10)$, increased heat waves $(\bar{X}=4.08)$, increased drought events $(\bar{X}=3.97)$, declining yield/output from crops $(\bar{X}=3.96)$ and increased rainfall intensity $(\overline{\mathrm{X}}=3.93)$. Rising atmospheric $\mathrm{CO}_{2}$ concentration, higher temperatures, changes in annual and seasonal precipitation patterns and in the frequency of extreme events are the usual features of climate change phenomenon and these features will affect the volume, quality, quantity, stability of food production and the natural environment in which agriculture takes place [15]. It was earlier found out that heat stress might affect the whole physiological development, maturation and finally reduce the yield of cultivated crops [17]. 
Table 2- Mean responses on the extent of effects/impacts of climate change on agriculture $(n=360)$

\begin{tabular}{lll} 
Effects/lmpacts of Climate change on agriculture & Mean & Std. Deviation \\
\hline Poor soil drainage & 3.85 & 1.09 \\
Increased soil erosion & 3.83 & 1.16 \\
Declining soil fertility & 4.15 & 1.11 \\
Increased weed infestation & 4.1 & 0.98 \\
Increased pest infestation & 3.87 & 1.13 \\
Increased diseases infestation & 3.77 & 1.23 \\
Premature ripening of crops & 3.26 & 1.22 \\
Erratic changes in production cycle & 3.72 & 1.14 \\
Declining yields/outputs from crops & 3.96 & 1.17 \\
Poor storage quality of crops & 3.75 & 1.23 \\
Increased vulnerability of wildlife ecosystem & 3.69 & 1.04 \\
Increased drought events & 3.97 & 1.1 \\
Increased flooding events & 3.65 & 1.3 \\
Increased rainfall intensity & 3.93 & 1.16 \\
Irregular rainfall distribution & 3.89 & 1.17 \\
Reduced water levels in rivers/streams & 3.45 & 1.28 \\
Decreasing fish population in rivers/streams & 3.37 & 1.28 \\
Reduced pasture availability & 3.47 & 1.15 \\
Increased heat waves & 4.08 & 1.01 \\
Reduced soil moisture & 3.63 & 1.15 \\
Increased wind storm & 3.81 & 1.2 \\
Increases in human health related problems & 3.76 & 1.08 \\
Sea level rise & 3.3 & 1.23 \\
drop in the production cycles of livestock & 3.49 & 1.21 \\
Declining vegetation covers & 3.62 & 1.26 \\
Increases in land areas reclaimed (in ha) in the past 10 years & 1.75 & 2.45 \\
Increases in the area of land lost (in ha) in the past 10 years & 1.74 & 2.44 \\
\hline & &
\end{tabular}

\section{Cut off point $=3.0$}

On the area of land gained in the past ten years, the result of the analysis show that an average of 1.75 ha of land was gained by the respondents. Similarly, about the same area of land was lost by the respondents in the past ten years. Some of the reasons given by the respondents for land gains include: area expansion, inheritance, purchase, renting, water level reduction and flood while those for loss of land include: building, land dispute, erosion, flooding, no rainfall and infertility issues.

\section{Activities of Farmers That Contribute To Climate Change}

The respondents were asked to indicate the extent to which they practice some suggested farm related activities that could contribute to climate change on a three point Likert-type scale. Results showed that the most dominant farm activity that could contribute to climate change was bush burning $(\bar{x}=2.66)$ (Table 3). Other activities include deforestation $(\bar{X}=2.42)$ and the use of chemical fertilizers $(\bar{x}=2.30)$. Bush burning is generally the preferred traditional means of clearing farmland for seedbed preparation, which increases the concentration of greenhouse gases and particulate matter in the atmosphere. With incidences of declining soil fertility being one of the most observed effects, farmers tend to increase their rate of use of chemical fertilizers in order to obtain meaningful harvests. This however exacerbates the greenhouse gas concentration in the atmosphere. The International Federation of Organic Agriculture Movement (IFOAM) [18] reported that conventional agricultural activities of farmers contribute to climate change because excessive amounts of nitrogen fertilizer is released as nitrous oxide and mines the earth of the nutrient needed to sustain production. Additionally, rainforest clearing through slash and burn techniques reduce carbon storage and releases huge amounts of carbon dioxide from burning vegetation. Moreover, burning of fossil oils $(\bar{x}=2.20)$, continuous cropping $(\bar{x}=2.16)$ and urine and other droppings from farm animals $(\overline{\mathrm{X}}=2.02)$ were also practiced by the farmers, all of which are possible sources of greenhouse gases. The rest of the activities as shown in Table 3 were not practiced by farmers significantly.

Table 3- Mean responses of farmers to the extent to which farmers engaged in practices that contribute to climate change $(n=360)$

\begin{tabular}{|c|c|c|c|}
\hline $\begin{array}{l}\text { Farmers' practices attributable } \\
\text { to climate change }\end{array}$ & Mean & $\begin{array}{l}\text { Std. } \\
\text { Deviation }\end{array}$ & $\begin{array}{l}\text { Farmers' perceived extent } \\
\text { to which the activities could } \\
\text { contribute to climate change }\end{array}$ \\
\hline Bush burning & 2.65 & 0.59 & 3.68 \\
\hline Continuous cropping & 2.16 & 0.81 & 2.89 \\
\hline Over grazing & 1.62 & 0.8 & 2.82 \\
\hline $\begin{array}{l}\text { Urine and other droppings from } \\
\text { farm animals }\end{array}$ & 2.02 & 0.81 & 2.48 \\
\hline Swamp rice production & 1.6 & 0.84 & 2.12 \\
\hline $\begin{array}{l}\text { Burning of fossil oils } \\
\text { (petrol, gas, kerosene) }\end{array}$ & 2.2 & 0.82 & 3.25 \\
\hline Use of Chemical fertilizers & 2.29 & 0.83 & 2.81 \\
\hline Deforestation & 2.41 & 0.7 & 3.69 \\
\hline The use of herbicides & 1.95 & 0.83 & 2.48 \\
\hline The use insecticides/pesticides & 1.97 & 0.84 & 2.55 \\
\hline Urbanization & 1.97 & 0.95 & 3.08 \\
\hline Industrialization & 1.81 & 0.93 & 3.06 \\
\hline Cement production & 1.65 & 0.93 & 2.65 \\
\hline Gas flaring & 1.76 & 0.97 & 2.91 \\
\hline
\end{tabular}

Cut off mark=2.0, Cut off mark $=3.0$

On the extent to which farmers think that each of the above activities contribute to climate change, results showed that farmers ranked the two farm activities mostly practiced by them namely; deforestation $(\overline{\mathrm{X}}=3.69)$ and bush burning $(\overline{\mathrm{X}}=3.68)$ as highest contributors to climate change. This suggests some level of awareness by the farmers that some of their activities contribute to climate change. This is particularly important because, awareness of climate problems and the potential benefits of taking action is an important determinant of adoption of agricultural and climate change adaptation technologies $[9,10]$. Other activities that contribute to climate change according to the farmers are burning of kerosene and other fossil fuels such as gas and petrol $(\overline{\mathrm{X}}=3.25)$, urbanization $(\overline{\mathrm{X}}=3.08)$ and industrialization $(\overline{\mathrm{X}}=3.06)$. Other activities, as their mean rankings suggest, do not contribute to climate change.

\section{Strategies for Agricultural Adaptation to Climate Change}

Table 4 presents the adaptation strategies adopted by farmers in the area in cushioning the effects/impacts of climate change. Results showed that the most intensively used adaptation practice was increased weeding $(\bar{x}=3.97)$. Other significant strategies adopted by farmers include; changing the timing of land preparation activities $(\overline{\mathrm{X}}=3.84)$, multiple cropping $(\overline{\mathrm{X}}=3.79)$, processing crops to minimize post-harvest losses $(\bar{x}=3.78)$, increased use of farm inputs such as manures and seeds $(\bar{X}=3.78)$, crop replacement, as earlier ones wither away due to unfavourable weather conditions $(\bar{x}=3.73)$, changing the planting dates $(\bar{x}=3.67)$, mixed farming $(\bar{X}=3.58)$, use of resistant varieties $(\bar{x}=3.46)$, changing the timing of harvesting dates $(\bar{x}=3.37)$, mulching/use of covercropping $(\overline{\mathrm{X}}=3.06)$ and relay cropping-planting and harvesting in succession $(\bar{x}=3.04)$. 
Table 4- Mean responses of farmers on the extent to which they apply the adaptation practices $(n=360)$

\begin{tabular}{|c|c|c|}
\hline Adaptation strategies & Mean & $\begin{array}{l}\text { Std. } \\
\text { Deviation }\end{array}$ \\
\hline Changing the timing of land preparation activities & 3.84 & 1.23 \\
\hline Changing the planting dates & 3.67 & 1.23 \\
\hline Changing the harvesting dates & 3.37 & 1.44 \\
\hline Water storage in ponds & 2.24 & 1.39 \\
\hline Groundwater harvesting & 2.11 & 1.31 \\
\hline Mulching/ use of cover crops & 3.06 & 1.49 \\
\hline Use of wetlands/ river valleys (e.g. Fadama) & 2.84 & 1.45 \\
\hline Irrigation schemes & 2.22 & 1.5 \\
\hline Multiple cropping & 3.79 & 1.32 \\
\hline Mixed farming & 3.58 & 1.39 \\
\hline Relay cropping- planting and harvesting in succession & 3.04 & 1.36 \\
\hline $\begin{array}{l}\text { Intercropping- main crops planted with subsidiaries at low } \\
\text { densities }\end{array}$ & 3.75 & 1.28 \\
\hline Contour cropping, across hill slopes & 2.19 & 1.43 \\
\hline Planting deeper or shallower than the usual planting depth & 2.21 & 1.4 \\
\hline Zero or minimum tillage & 2.72 & 1.51 \\
\hline Construction of drainage systems & 2.22 & 1.43 \\
\hline Afforestation - planting of trees & 2.5 & 1.47 \\
\hline Use of resistant varieties & 3.46 & 1.43 \\
\hline Decreasing animal stock & 2.63 & 1.42 \\
\hline Culling of infected animals & 2.98 & 1.38 \\
\hline Processing crops to minimize post-harvest losses & 3.78 & 1.34 \\
\hline Destruction of infected farms & 2.6 & 1.51 \\
\hline Crop replacement & 3.73 & 1.28 \\
\hline Use of weather forecasts & 2.25 & 1.34 \\
\hline Shortened fallow & 2.92 & 1.52 \\
\hline Lengthened fallow & 2.83 & 1.6 \\
\hline Expansion of cultivated land area & 2.99 & 1.46 \\
\hline Increased use farm inputs e.g. manures, seeds & 3.78 & 1.35 \\
\hline Cultivation on marginal lands & 2.58 & 1.58 \\
\hline Change from crop production to livestock production & 1.93 & 1.34 \\
\hline Change from animal production to crop production & 1.95 & 1.37 \\
\hline Agro-forestry practice & 2.53 & 1.61 \\
\hline $\begin{array}{l}\text { Change from crop/livestock production to marketing of } \\
\text { agricultural products }\end{array}$ & 1.93 & 1.37 \\
\hline Intensive manure application & 3.38 & 1.38 \\
\hline Increased weeding & 3.97 & 1.27 \\
\hline Use of law enforcements & 1.76 & 1.24 \\
\hline Total change from farming to other occupations & 1.84 & 1.25 \\
\hline Planting Shallower than the usual planting depth & 1.92 & 1.27 \\
\hline Out Migration from Climate risk zones & 1.89 & 1.32 \\
\hline Construction of elevated homesteads and farmsteads & 2.1 & 1.36 \\
\hline Group approach to climate risk management & 2.01 & 1.38 \\
\hline Construction of dams within the farm/household & 1.7 & 1.26 \\
\hline
\end{tabular}

\section{Cut off mark=3.0}

One of the most significant effects of climate change on farms is increased weed infestation. To respond to this challenge, farmers noted that they have to weed their farms frequently if they are to obtain any meaningful harvest. In a similar study, farmers reported that they had to weed their farm plots more than three times in order to obtain any significant harvest from the farm [19]. This was against one or two times that they had previously weeded a typical farm plot some two decades ago. Previous studies have also shown that some proven adaptation practices of farmers were through the diversification of crops planted, use of resistant varieties, multiple cropping and increased use of inputs [20]. Moreover, processing crops generally enhances their value and storability. For instance, it was discovered that processing makes cassava roots easier to transport, gives them longer shelf-life, removes the cyanogenic compounds and improves their palatability [21].

\section{Household Socioeconomic Determinants Influencing Farm- ers' Adaptation to Climate Change}

Table 5 presents the results of the determinants of adaptation practices using the probit regression model. The practices (dependent variables) were grouped into: (a) agronomic; for adaptations like adjusting the timing of farm operations in response to weather variations, multiple/intercropping, mulching etc, (b) technological; for those that pertain to the use of some kind of technologies such as groundwater harvesting, irrigation, construction of drainage systems etc, (c) environmental; such as afforestation and destruction of infected farms, (d) institutional; such as use of law enforcement agencies and weather forecasts, (e) economic; such as processing crops to minimize post-harvest losses and changing from farming to other occupations and (f) social practices, for those that pertain to the use of group actions. The analysis was done using the probit regression model essentially because the dependent variable was categorized into 1, if farmer used the adaptation practices in each of the above groups and 0 otherwise. The results of the analysis show that the explanatory powers of the specified variables seem low, but this is not uncommon in cross-sectional analysis. A similar coefficient of determination was earlier reported [22]. The overall goodness of fit as reflected by prob>chi2 was however very good $(<0.001)$ in almost all the specifications. [See Table 5 on Page 251]

Age was positively and significantly related with the use of agronomic adaptation practices. Older farmers generally have more experience and are able to take healthier production decisions than younger ones [23]. This is particularly relevant for agronomic practices that have to do with routine farm specific duties. Farming as a major occupation was negatively and significantly related with agronomic adaptation practices. This is surprising and counter-intuitive. The expectation is that those with farming as their major occupation will devote more of their time to the farm and hence acquire deeper knowledge of the farm than those with other major occupations, which should help them to adjust to climate change matters faster. However, the adaption practice being considered need not require all that much experience because it pertains to routine farm duties as noted earlier. Farm size was positive and significantly related with agronomic adaptation practices. This is to be expected as larger farms will generally entail greater farm investments, which should drive greater adaptation practices to ensure reasonable returns. The two variables on awareness of climate change were all positive and significantly related with agronomic adaptations. These are whether a farmer has had about climate change before and whether he/she thinks climate change will affect agriculture. The awareness of climate problems and the potential benefits of taking action is an important determinant of adoption of agricultural technologies [9].

On technological adaptation practices, marital status was positive and significantly related with the dependent variable. Technological adaptation will most likely be labour intensive as some of them require some kind of construction. Married farmers may therefore have the necessary family labour, which is also cheap, to engage in such practices. Farming as a major occupation was positively and significantly related with technological adaptation. In contrast with agronomic adaptation, technological adaptation may require a lot of dedication to farm duties, which only full time farmers can provide. Income was also positively and highly significantly related 
with the dependent variable. Technological adaptation may not only be labour intensive but also material intensive, which only farmers with enough money can provide. A similar study earlier reported that poverty is a major constraint to farmers' climate change adaptation practices [23]. In addition, it was observed that for farmers to apply purchased inputs in the right quantity and adopt innovations, they should be sufficiently empowered financially [24].

For environmental related adaptation practices, household size was positive and significantly related with the dependent variable. As in the case of technological practices, this may also have to do with cheap farm labour, which large households could provide for the farmers. For instance, afforestation, which is a component of this, will require much labour, not only for planting the trees but also for tending them to maturity. Income was also positively and highly significantly related with environmental related adaptation practices. The above explanation for income under technological adaptation also applies for environmental adaption practices. Experience was positively and significantly related with the dependent variable. Environmental adaptation may involve delicate decisions like the timing of destruction of infected farms, which can only be perfected with experience.

Farming as a major occupation was positively and highly significantly related with economic adaptation practices. It is only those whose major source of income is farming that will be highly sensitive to fluctuations in the fortunes of farming and hence will largely bother with economic adaptation practices. This will help ensure a stable source of income for them. Income was also positively and significantly related with economic adaptation. Economic adaptations could be resource intensive, for instance, processing of crops to avoid post-harvest losses. In such cases, the same amount of resources may be needed for processing, as it is for production. It was earlier reported that as much labour is required for processing cassava roots into gari is also used in producing the roots themselves [22]. Awareness of climate change was also positive and significantly related with the dependent variable.

Gender ( 1 if male and 0 otherwise) was positively and significantly related with institutional adaptations. This is to be expected as men generally listen to the radio and television, where weather forecasts are usually broadcast, more than women. Farming as a major occupation was positively and significantly related with the dependent variable. In general, only those whose major source of income is farming can go into the extra expenses of using law enforcement agencies for instance, to secure their farm against trespassers and animal invaders. Income was also positively and significantly related with institutional adaptation. This is not surprising because, only farmers who have the means can afford to buy radios and televisions in order to listen to weather forecasts. Awareness of climate change was also positive and significantly related with institutional adaptation. Radio and television are also sources of climate change awareness. Experience was however negatively and significantly related with the dependent variable. It does not require experience for a farmer to use weather forecasts, for instance. The only requirement for this is to have the information, which can be obtained from a variety of sources like radio, television, internet, friends etc.

The level of education of the farmer was positive and significantly related with the use of social adaptation practices. In group inter- actions, a farmer is likely to be presented with a variety of alternative ways of dealing with the issue of climate change. Education equips one with a better understanding of how to process information provided by different sources regarding new farm technologies, thereby increasing his/her allocative and technical efficiency. Farming as a major occupation was also positively and significantly related with the dependent variable. The membership of cooperatives in Enugu state is predominantly rural smallholder farmers, whose major source of income is in most cases farming [24]. Income was positive and significantly related with the adaptation practices. Being an active and functional member of a group will necessarily require money.

\section{Government Policies and Programmes on Climate Change Adaptation}

Results on government policies and programmes on climate change adaptation revealed that majority $(87 \%)$ of the respondents indicated that they were aware of the government ban on indiscriminate bush burning, but about half of them $(50 \%)$ said that the policy is not effectively being implemented (Table 6). This is not surprising because the farmers most often use bush burning as a means of clearing farmland for cultivation, and it ranked as the highest farm practice above. On gas flaring, majority of the farmers $(65 \%)$ said they were not aware of the policy. Similarly, $88 \%$ of the farmers indicated that the policy is not effectively being implemented. Although majority of the respondents (65\%) agreed that they were aware of government policy on promotion of afforestation, majority of them (59\%) however said that the policy was not effectively being implemented. This could be because, not only were the farmers involved in direct deforestation for farmland area expansion and firewood harvesting, but also involved in bush burning which is a deforestation process. The respondents were also mostly (65\%) aware of government ban on indiscriminate tree felling but majority $(64 \%)$ also indicated that the policy is not effectively being implemented.

Table 6- Percentage distribution of respondents based on their perception of government policies/programmes on climate change adaptation $(n=360)$

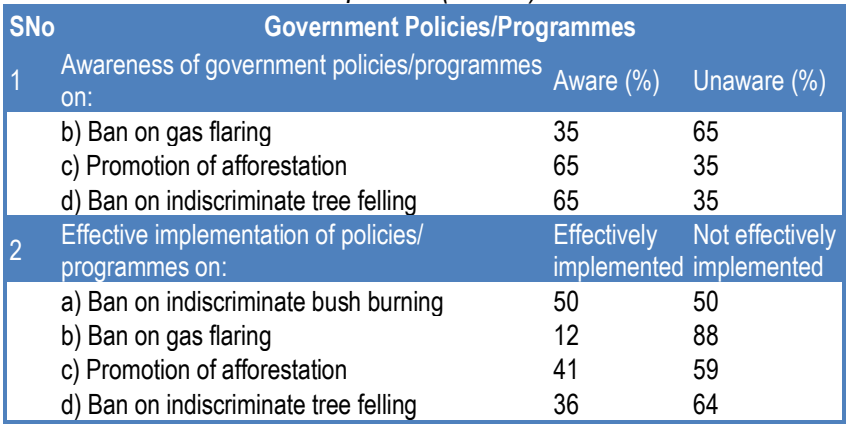

\section{Framework for Agricultural Adaptation to Climate Chang}

Based on the key findings from the research study, the series of observations and interactions with stakeholders, the multiple focus group discussions held with farmers and other stakeholders, and extensive review of relevant literature on the subject matter, the following framework (Fig. 2) for agricultural adaptation to climate change in Southern Nigeria is hereby proposed. Note that the 
mitigation and adaptation options combine both indigenous and modern techniques, processes, practices and technologies. However, the framework does not in any way suggest a hierarchical order of either impacts or adaptation options nor is it suggesting that all the components could be applicable to a particular farmer. This is because any or some of them could manifest for a particular farmer. It is therefore necessary for individual, community and national bodies to firstly conduct situational analysis of their respective peculiarities before adopting any of the adaptation or mitigation options [See Fig. 2 on Page 252].

\section{Conclusion and Recommendations}

The research has shown that most farmers in Southern Nigeria are aware of climate change as manifested in increasing flooding and drought events; changes in rainfall intensity and distribution; increase in temperature; high incidences of pests, diseases and weeds; declining soil fertility and decreases in crop yields among others. However, their understanding of the concept of global climate change with regard to greenhouse gas emissions, ozone layer depletion, etc is limited. Such terminologies are poorly understood and there is no standard translation of what climate change means in local languages. Although farmers adopted numerous adaptation strategies to climate change effects/impacts, they noted that most of the strategies are increasingly tasking and might not stand the test of time especially with the increasing impacts of climate change. Grouping the adaptation strategies into agronomic, technological, environmental, economic, institutional and social, and applying the probit regression model, the major household level factors driving their adoption were farming as a major occupation and level of income of the farmer. Even though farmers were aware of some government policies and programmes aimed at environmental protection such as the ban on indiscriminate bush burning, the ban on indiscriminate felling of trees, and the tree planting programme, they confirmed that these policies and programmes were not being effectively implemented. Based on the key findings from the research study, the following recommendations are proffered:

- There is need to increase the awareness level of farmers and the public as a whole on climate change issues. The people's ability to effectively respond to climate change challenges is determined by the quality of the information available to them and how easily they can access it. It is based on the information the people have that they can make informed judgements and decisions for adaptation. The role of awareness creation is that of everybody, but a responsive government should take the lead.

- There is need for a systems approach involving all stakeholders- science experts and researchers; policy makers and governments; private sectors; non-governmental and civil society organizations; farmers groups; youth and women- to work together in turning the challenges posed by climate change into opportunities. The systems approach will lead to the development of effective climate change resilient capacity, knowing that systems thinking espouse the principles of collaboration which breeds innovation.

- While the indigenous practices adopted by farmers over the years have helped them cope with the changing climate, it is necessary to apply the modern technologies and practices for effective adaptation to take place. This is because, with time, some of the indigenous methods and practices of adaptation will not be effective again. A framework for agricultural adaptation to climate change in Southern Nigeria (Fig. 2) developed through this research study can provide useful reference material for adaptation options in the area.

- There is need for climate change policy at national, state, and local government levels in the country. Such policies should streamline roles and responsibilities, strategies for adaptation, vulnerability scenarios, and stakeholder's involvement in a systematic manner. Regular debates, workshops, conferences, international affiliations should be used to provide updates on climate change issues.

- There is need to climate-proof all courses in universities. This means that the environmental implications of courses taught in universities should be emphasized as part of curriculum review. Besides, new courses in relevant disciplines should be offered especially at postgraduate levels to provide in-depth knowledge on climate change science; adaptation and mitigation; agrobiodiversity; pastoralism; climate extension and economics; global warming, policy issues; etc.

- Finally, there is need to utilize the power of the media- radio, television, newspapers, posters, internet, hand bills, bill boards, etc- in strengthening climate change awareness and in communicating effective response strategies to climate change. Communicating climate change involves the provision of information, facilitating policy and public dialogue, and encouraging accountability.

\section{Acknowledgements}

We wish to thank the British Department for International Development (DFID) for providing the funds used to conduct this research under the Development Partnerships in Higher Education (DelPHE) programme. We appreciate the British Council, Nigeria for the effective implementation of the DeIPHE programmes in Nigeria and all the participating institutions in the DeIPHE 326 Project including; University of Nigeria, Nsukka (UNN); African Institute for Applied Economics (AIAE), Enugu; and the University of Reading (UoR), United Kingdom.

\section{References}

[1] Parry M.L., Canziani O.F., Palutikof J.P., Van der Linden P.J. and HansonIntergovernmental C.E. (2007) Contribution of Working Group II to the Fourth Assessment Report of the Intergovernmental Panel on Climate Change, 976.

[2] German Advisory Council on Global Change (WBGU) (2005) World in Transition, Fighting Poverty through Environmental Policy. Earthscan, London.

[3] Ozor N. (2009) African Institute for Applied Economics (AIAE), Enugu, Nigeria, 25-42.

[4] Ozor N., Madukwe M.C., Enete A.A., Amaechina E.C., Onokala P., Eboh E.C., Ujah O. and Garforth C.J. (2010) Journal of Agricultural Extension, 14(1), 114-124.

[5] Pittock A.B. (2005) Climate Change, Turning up the Heat. London, Earthscan, 1-23.

[6] German Advisory Council on Global Change (WBGU) (2003) Climate Protection Strategies for the 21st Century, Kyoto and beyond. Special Report. Berlin, Germany, WBGU, 1. 
[7] Intergovernmental Panel on Climate Change (IPCC) (2001) Contribution of Working Group II of the Intergovernmental Panel on Climate Change to the Third Assessment Report of IPCC. London.

[8] Ozor N. and Nnaji C. (2010) Journal of Agricultural Extension, 14(2), 106-122.

[9] Hassan R. and Nhemachena C. (2002) AFJARE, 2(1), 85104.

[10]Maddison D. (2007) Centre for Environmental Economics and Policy in Africa (CEEPA). 10, CEEPA, University of Pretoria.

[11]Araya B. and Adjaye J.A. (2001) Indian Journal of Agricultural Economics, 56, 239-252.

[12]Anim F.D.K. (1999) Journal of Agricultural Economics, 50, 336 -345 .

[13]Science in Africa (2007) Africa's first on-line science magazine.

[14]Magadza C.H.D. (2000) Environmental Monitoring and Assessment, 61, 163-205.

[15]Brussel S.E.C. (2009) Commission of the European communities. Commission working staff working document accompanying the white paper, 147.
[16]Mark W.R., Mandy E., Gary Y., Lan B., Saleemul H. and Rowena V.S. (2008) Federal Ministry for Economic Cooperation and Development, Germany.

[17]Khanal R.C. (2009) The Journal of agriculture and environment, 10, 100-110.

[18] International Federation of Organic Agriculture Movement (IFOAM) (2007) Organic agriculture's role in countering climate change. IFOAM, Germany.

[19]Ozor N. and Nnaji C. (2011) Journal of Agricultural Extension and Rural Development, 3(3), 42-50.

[20]Benhin J.K.A. (2006) CEEPA Discussion, 21. CEEPA, University of Pretoria, South Africa.

[21]Enete A.A., Nweke F.I. and Tollens E. (2004) Journal of International Agriculture, 43(1), 57-69.

[22]Nweke F.I. (1996) COSCA, 14, COSCA, IITA, Ibadan, Nigeria.

[23]Enete A.A., Madu I.I., Mojekwu J.C., Onyekuru A.N., Onwubuya E.A., and Eze F. (2011) ATPS, 53.

[24]Enete A.A. and Achike I.A. (2008) Outlook on agriculture, 37 (2), 131-134

Table 5- Parameter Estimate of the Probit Regression Model

\begin{tabular}{|c|c|c|c|c|c|c|}
\hline Explanatory Variable & Agronomic & Technological & Environmental & Economic & Institutional & social \\
\hline Household size & $0.32(1.04)$ & $0.02(0.69)$ & $0.05(1.75)^{*}$ & $0.03(0.90)$ & $-0.02(-0.58)$ & $0.02(0.57)$ \\
\hline Education & $-0.01(-0.42)$ & $0.03(1.49)$ & $-0.003(-0.14)$ & $0.01(0.37)$ & $-0.002(-0.09)$ & $0.05(1.77)^{\star}$ \\
\hline Marital status ( 1 if married, else 0 ) & $0.35(1.46)$ & $0.50(1.86)^{*}$ & $0.30(1.24)$ & $0.27(1.02)$ & $0.30(1.14)$ & $0.29(0.92)$ \\
\hline Gender ( 1 if male, else 0 ) & $-0.23(-1.06)$ & $-0.33(-1.49)$ & $-0.08(-0.39)$ & $-0.26(-1.20)$ & $0.38(1.78)^{\star \star}$ & $0.08(0.32)$ \\
\hline Occupation ( 1 if farming was major, else 0 ) & $-0.41(-1.65)^{*}$ & $0.97(3.54)^{\star \star *}$ & $0.18(0.81)$ & $0.72(2.75)^{* * \star}$ & $0.63(2.52)^{\star * *}$ & $0.74(2.40)^{\star \star}$ \\
\hline Income & $-2.34 \mathrm{e}-08(-0.06)$ & $1.53 e-06(3.95)^{\star \star \star}$ & $1.22 \mathrm{e}-06(3.11)^{\star \star *}$ & $8.67 e-07(2.71)^{\star \star *}$ & $9.59 \mathrm{e}-07(2.84)^{\star \star *}$ & $7.96 \mathrm{e}-07(2.38)^{\star \star}$ \\
\hline Farm size & $0.20(2.71)^{\star * \star}$ & $-0.04(-0.89)$ & $0.05(1.12)$ & $0.03(0.77)$ & $-0.01(-0.15)$ & $-0.05(-0.94)$ \\
\hline Aware of climate change (Yes/No) & $0.59(2.31)^{\star \star}$ & $0.06(0.23)$ & $0.19(0.79)$ & $1.24(3.32)^{\star * \star}$ & $0.48(1.71)^{*}$ & $0.21(0.61)$ \\
\hline Climate change will affect agric (Yes/No) & $2.02(3.55)^{\star * *}$ & $-0.37(-0.71)$ & $0.21(0.43)$ & $0.12(0.20)$ & $-0.22(-0.44)$ & - \\
\hline Experience & $-0.01(-0.81)$ & $-0.02(-1.49)$ & $0.02(2.02)^{\star *}$ & $-0.02(-1.61)$ & $-0.02(-1.70)^{*}$ & $-0.002(-0.19)$ \\
\hline Intercept & $-3.00(-3.71)^{\star * *}$ & $-2.29(-3.05)^{* * *}$ & $-1.73(-2.54)^{\star * *}$ & $-3.28(-3.93)^{\star * *}$ & $-1.11(-1.63)^{*}$ & $-3.18(-4.41)^{\star * *}$ \\
\hline Statistics: No. of obs. & 243 & 243 & 243 & 243 & 243 & 234 \\
\hline LR chi² & 43.59 & 40.01 & 37.18 & 43.13 & 34.02 & 20.62 \\
\hline Prob $>$ chi $^{2}$ & $<0.001$ & $<0.001$ & $<0.001$ & $<0.001$ & $<0.001$ & 0.02 \\
\hline Pseudo R2 & 0.162 & 0.141 & 0.113 & 0.149 & 0.118 & 0.101 \\
\hline
\end{tabular}

Figures in parenthesis are Z-ratios. ${ }^{* * *}=$ significant at $1 \%,{ }^{* *}=$ significant at $5 \%$ and ${ }^{*}=$ significant at $10 \%$ probability. 


\section{Climate Change Effectsilmpacts}

\section{Adaptation and Mitigation Options}

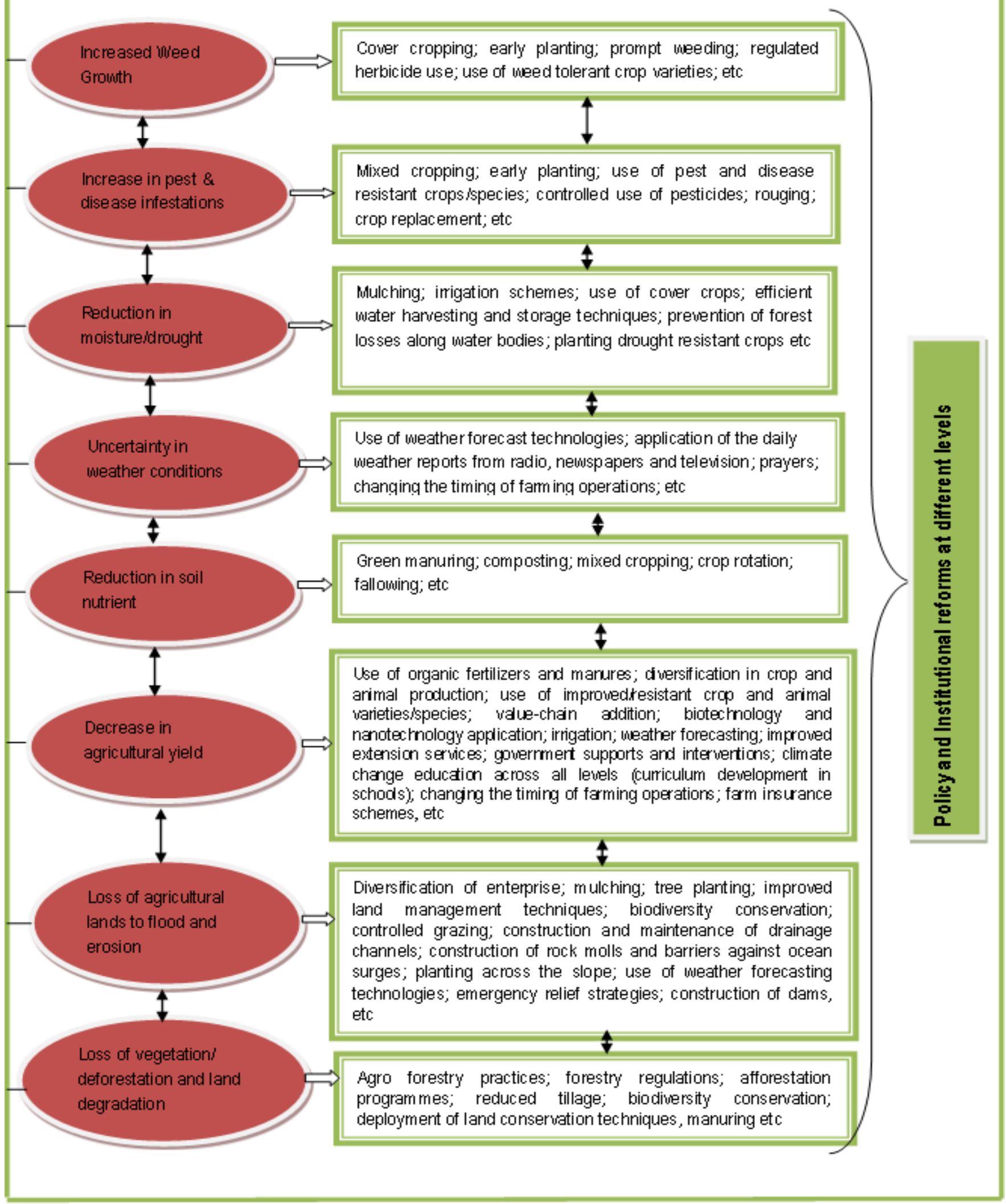

Fig. 2- A Framework for mitigating and adapting to climate change impacts on agriculture in Southern Nigeria 